\title{
EFFECT OF ALUMINIUM AND ALUMINA ON THE LUNG IN GRINDERS OF DURALUMIN AEROPLANE PROPELLERS
}

BY

\author{
DONALD HUNTER, R. MILTON, KENNETH M. A. PERRY, and D. R. THOMPSON
}

From the Department for Research in Industrial Medicine (Medical Research Council), The London Hospital, and the De Havilland Aircraft Company

\section{M.R.C. Investigations in 1936}

In 1936 the Industrial Pulmonary Disease Committee of the Medical Research Council investigated both clinically and radiologically a group of fifty workers who had been exposed for a number of years to the inhalation of alumina in the reduction factory of the British Aluminium Company. The results are shown in Table 1.

They also considered the sickness records of all the workers (Hill, 1936), as compared with those in other parts of the factory (Table 2).

The dust cloud consisted of alumina with small proportions of aluminium and sodium fluorides, sodium oxide, and cryolite. The number of particles per ccm. varied from 400 to 2430 , and median sizes of particles over the whole series were between $0.23 \mu$ and $0.5 \mu$. The Committee after reviewing these findings was unable to find any evidence that the inhalation of alumina dust had caused fibrosis of the lung.

\section{Other Investigations}

Denny, Robson, and Irwin (1937) successfully used 1 per cent. grease-free metallic aluminium powder of a particle-size below $5 \mu$ in the prevention of silicosis; and in 1939 they showed that on being converted into hydrated alumina it reduced the toxicity of quartz in tissues by flocculation, absorbing silica from solution, but chiefly by coating the quartz particle with an insoluble and impermeable coating which is gelatinous hydrated alumina. This on drying forms the crystalline alpha aluminium monohydrate $\left(\mathrm{Al}_{2} \mathrm{O}_{3} \mathrm{H}_{2} \mathrm{O}\right)$. Dust inhalation experiments in animals showed that metallic aluminium

TABLE 1

\begin{tabular}{|c|c|c|c|c|c|c|}
\hline Age group & $\begin{array}{l}\text { No. of men } \\
\text { examined }\end{array}$ & $\begin{array}{c}\text { Years of work } \\
\text { in furnace-room }\end{array}$ & $\begin{array}{c}A \\
\text { No changes } \\
\text { clinically or } \\
\text { radiologically }\end{array}$ & $\begin{array}{c}B \\
\text { Clinical } \\
\text { and } x-r a y \\
\text { changes }\end{array}$ & $\begin{array}{c}C \\
\text { Clinical } \\
\text { changes } †\end{array}$ & $\begin{array}{c}D \\
\text { Radiological } \\
\text { changes } \ddagger\end{array}$ \\
\hline $\begin{array}{l}20-29 \\
30-39 \\
40-49 \\
50-59 \\
60-69\end{array}$ & $\begin{array}{r}6 \\
12 \\
10 \\
14 \\
8\end{array}$ & $\begin{array}{r}6-12 \\
6-18 \\
11-25 \\
14-34 \\
12-39\end{array}$ & $\begin{array}{l}3 \\
7 \\
5 \\
9 \\
6\end{array}$ & $\begin{array}{l}3 \\
1 \\
1\end{array}$ & 1 & $\begin{array}{l}3 \\
4 \\
2 \\
4 \\
1\end{array}$ \\
\hline Total .. & 50 & $6-39$ & 30 & 5 & 1 & $\overline{14}$ \\
\hline
\end{tabular}

TABLE 2

NUMBER OF SICKNESSES RECORDED UNDER GIVEN DIAGNOSES

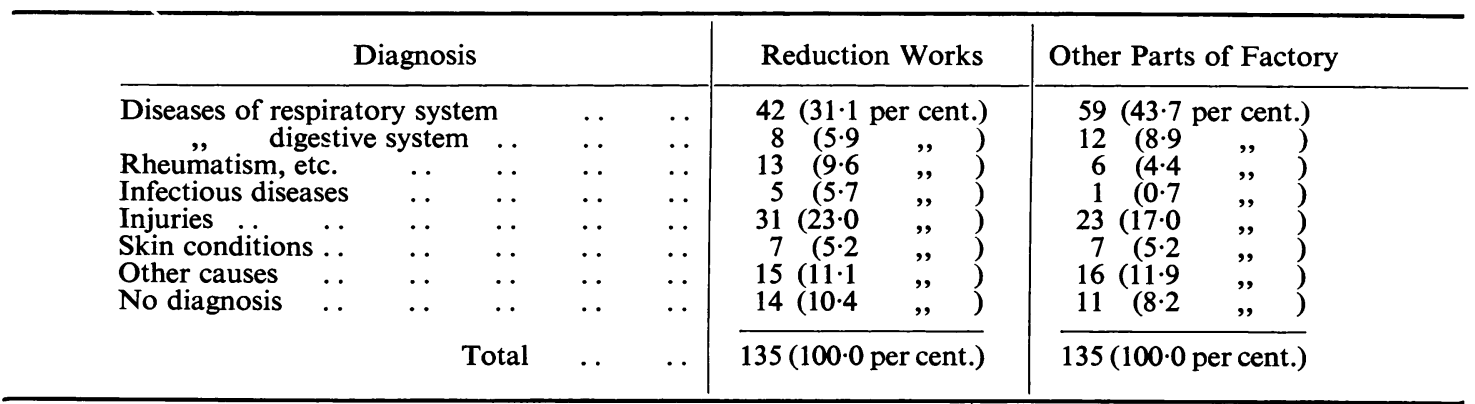

* Previous pneumonia, asthma, catarrh, chronic bronchitis, fibrosis.

‡ Slightly increased stratum 3, evidence of old pleurisy 3, slight emphysema 4, calcified glands 2, catarrh 2.

† Bronchial catarrh. 
alone produced no fibrosis or other significant pulmonary reaction. Eight rabbits were exposed to an atmosphere containing freshly ground finely particulate aluminium powder in a concentration averaging 7000 particles per cc. 12 hours daily for 14 months. Following the cessation of the dust exposure some of the animals were observed for a further seven months. Chemical assays of the lungs showed them to contain from 270 to $1200 \mathrm{mg}$. of aluminium per $100 \mathrm{~g}$. of dried tissue. During their lifetime these animals gained normally in weight, and from the appearance and texture of the fur and their general behaviour there was no evidence of any harmful effect due to the inhalation of the aluminium dust.

The lungs showed a uniform dark mottling of the pleural surfaces and on sectioning this was seen to be distributed uniformly throughout. Microscopically the mottled areas were shown to be aggregates of dust cells almost completely filling adjacent alveolar spaces. These cells contained irregular shaped opaque particles, the majority being under $3 \mu$ in diameter. Practically all these particles were present in the dust cells. These cells presented regular outlines and their nuclei stained well. The alveolar walls throughout the lung showed no evidence of thickening except occasionally in the dustcontaining areas. This thickening consisted of a slight alveolar endothelial proliferation. The ciliated epithelial lining of the bronchial tree appeared normal. The lymphatic spaces and aggregates throughout the lung contained relatively few dustladen cells, and showed no evidence of thickening or damage.

Goralewski (1943) has described symptoms arising in aluminium workers in Germany. He investigated 700 workers exposed to metallic aluminium and made vital capacity and sputum tests on 125 and blood counts and sedimentation rates on 100 . These workers complained of dry cough with pain on breathing, shortness of breath, poor appetite, and gnawing abdominal pain. Spontaneous pneumothroax developed in four instances (1941). They were making aluminium powder; 1 gr. aluminium powder contains about four milliards of particles of dust, but no account is given of the environmental conditions in which the men worked. The chemical composition, concentration and particle-size of the dust in the atmosphere is not stated. No abnormal physical signs are described. The blood counts showed normal white cells with a relative lymphocytosis and an eosinophilia of up to 10 per cent. The sedimentation rate was within normal limits in 78 per cent. of the cases. The vital capacity was decreased in 27 instances. The x-ray appearances consisted of focal shadows in the apical regions with an increase of normal bronchial markings in the upper and middle thirds of the lung giving a reticular appearance. There was sometimes an increase in these markings in the lower lobes, suggesting increased drainage to the hilar glands. Retraction of the diaphragm and distortion of the heart shadow were found. At a later stage the focal shadows tend to increase and become confluent. Definite changes were found amongst 24 of the first 125 cases (1940). The development of the illness is rapid and appears to bear no relation to the length of exposure. It may develop in as short a period as nine months.

One patient died, and histological examination of the lungs after necropsy revealed coarse branching hyaline collagenous fibres, enclosing phagocytes containing fine and coarsely granular particles which differed from carbon particles by their jagged outlines. In parts of the lung these hyaline collagenous fibres were found surrounding the walls of the alveoli, which contained phagocytes. The changes were most marked in the right upper lobe. The regional lymph glands exhibited a few of these dust cells lying chiefly in small groups. These histological changes, he suggested, result from a colloidal reaction between aluminium dust particles and the tissue fluids.

According to Jäger and Jäger (1941) the statements of Goralewski are supported by their practical experimental work. These authors point out that while aluminium powder is highly resistant to aerial oxidation and to water, it is freely soluble in sodium chloride solutions (with the evolution of hydrogen). The resulting solution contains aluminium chloride and sodium aluminate in a condition of equilibrium, and if the sodium and chloride ions are allowed to diffuse away, then a colloidal aluminium hydroxide complex results. They state that if this reaction with aluminium powder is allowed to take place in biological media, which contains protein as well as sodium chloride, then the protein is 'tanned' and is co-precipitated with the aluminium hydroxide complex round the partly dissolved aluminium particle. This system is said to be highly resistant to solution and phagocytosis, and if it takes place in the lung tissue then results in the clinical condition which Goralewski calls 'aluminium lung.' Histological evidence is brought forward in support of the above contention, and the theory is extended to explain the good effect reported of the use of aluminium powder in the prevention of silicosis.

Koelsch (1942) reviewed this experience with 150 workers. He believed, however, that mechanical factors were primarily responsible for the changes and that unsatisfactory ventilation of industrial workrooms because of black-out rules was to a large extent responsible. This seems to us a more reasonable explanation, and possibly has a bearing on the discrepancy with our investigation.

Evang (1938) in Norway, Riedl (1939) in Czechoslovakia, and Cotter (1943) in the United States have described cases of bronchial asthma following exposure to aluminium. However, the fact that so few cases have been reported indicates that very few people show sensitivity to this metal.

\section{Present Investigation}

In view of the definite findings by German workers it was decided that a thorough investigation was needed of the health of aeroplane propeller grinders 
in England, especially as several of them were complaining of respiratory symptoms. During this war Duralumin, which is an alloy of 95 per cent. aluminium, 3.5 to 4.5 per cent. copper, 0.4 to 0.7 per cent. manganese and 0.4 to 0.8 per cent. magnesium, not more than 0.7 per cent. silicon, 0.7 per cent. iron, and $0 \cdot 3$ per cent. titanium, has been used for making aircraft propellers. These propellers are ground smooth with alundum wheels (calined aluminium oxide 95 to 97 per cent., ferric oxide $0 \cdot 3$ to $0 \cdot 6$ per cent., titanium oxide $2 \cdot 2$ to $2 \cdot 8$ per cent., and silica $0 \cdot 2$ to 0.4 per cent.). This process creates much dust and despite good ventilation the workers become covered with the dust and assume an aluminium colour as will be seen in the illustrations (Plate I).

Factory Conditions. A comprehensive study of the environmental conditions has been carried out in the particular factory under review. The factory building consists of a rectangular construction $120 \mathrm{ft} . \times 68 \mathrm{ft} . \times 17 \mathrm{ft}$. high. It has a dual ventilation system, first dealing with the general atmosphere, and secondly fitted to individual benches where the dust is extracted as produced. The general atmosphere ventilation ensures eighteen air changes per hour. The individual ventilation operates through a slatted bench below the worker and aims at withdrawing downwards the aluminium particles. The air-change capacity at each bench rated in velocity of each fan per unit is 1660 cubic feet per minute.

The shop is divided mainly into two parts, one concerned with cutting and the other with finishing. The cutting tools produce large aluminium shavings and no dust. Finishing is divided into two processes, grinding and polishing. Grinding is carried out by means of a rotating disc faced with an alundum abrasive paper. The disc is driven by a flexible drive and hand directed. The disc is pressed on to the aluminium and the fine particles are thrown in a horizontal direction, the bulk being carried away through the slats of the bench by the ventilation system (Fig. 1). Four different grades of abrasive disc are used, beginning with a very coarse paper, and becoming progressively finer. The size of the aluminium particle cut away is thus dependant upon the fineness of the abrasive. Polishing is carried out by means of a buffer wheel also with flexible drive and hand directed. The buffer wheel is of the multiple-linen disc type and is edged with a composition of alundum and adhesive which is allowed to dry before use. The particles are very much finer than those obtained by the grinding process, and since the throw is mainly in a vertical direction the scatter of particles is greater than with any other process.

Physical Analyses. Measurement of the atmosphere content of aluminium has been found by chemical estimation, and assessment of the particle size by means of the thermal precipitator. Chemical sampling is carried out by suction of a known volume of air through a paper filter fixed into an ebonite cone. This is maintained at the operator's mouth level during sampling. The aluminium is extracted from the paper by dilute acid and estimated gravimetrically with 8-hydroxy quinoline if the sample is sufficiently large, or colorimetrically as the lake with aurin carboxylic acid if micro quantities are involved. The colorimetric method of Front and Kirsner (1942) adapted for use with the Spekker photo-electric absorptiometer has been used in this connection.

The following results have been obtained with sampling at the various points in the factory, and represent the average of a number of determinations made at different times.

Grinding Process.-The average concentration of aluminium in the atmosphere close to the operator's mouth as measured chemically in the manner described above is of the order of 3-5 mgs. $/ \mathrm{m}^{3}$. The bulk of this consists of large particles of aluminium made up as follows :-

Particles $7 \mu$ and upwards (less than 1 per c.c.)

$$
\begin{array}{r}
=2 \mathrm{mg} . / \mathrm{m}^{3} \\
\quad, \quad 2-7 \mu \quad(6 \text { particles per c.c.) } \\
=1 \mathrm{mg} . / \mathrm{m}^{3}
\end{array}
$$

The light fraction has been collected and examined by the thermal precipitator technique and has been shown to exist almost exclusively of transparent particles less than $1 \mu$. This must therefore be composed of the aluminium oxide abrasive. The number of particles per c.c. is about 5200 of which

$$
\begin{aligned}
& 3325 / \text { c.c. }<0.2 \mu \quad \equiv 0.03 \mathrm{mg} . / \mathrm{m}^{3} \\
& 1750 / \text { c.c. between } 0 \cdot 2 \mu \text { and } 0 / 4 \mu \equiv 0 \cdot 16 \text {, } \\
& 125 / \text { c.c. " } 0.4 \mu \text { and } 0.8 \mu \equiv 0.05 \quad \text { " } \\
& \text { Total .. } \overline{0.24} \text {,, }
\end{aligned}
$$

At the polishing bench the amount of dust present at operative level is of the order of 50 to $100 \mathrm{mg} . / \mathrm{m}^{3}$, depending on the direction of the buffing wheel. This consists almost exclusively of large aluminium particles, but with a significant fine fraction again transparent in appearance and therefore obtained from the alundum abrasive.

The distribution is as follows :-

Coarse Fraction.-

Particles $7-40 \mu(12$ particles/c.c. $) \equiv 95 \mathrm{mg} . / \mathrm{m}^{3}$

$$
, \quad 2-7 \mu(8 \text { particles/c.c. }) \equiv 1 \cdot 4 \quad,
$$

Fine Fraction.-(Mainly transparent.)

3000 particles per c.c. less than $2 \mu$ comprised or $1600 /$ c.c. $<0 \cdot 4 \mu \stackrel{<0}{1150 / \text { c.c. } 0 \cdot 4-0 \cdot 8 \mu} \equiv 0.5 \mathrm{mg} . / \mathrm{m}^{3}$
$350 /$ c.c. $350 /$ c.c. $\quad 0 \cdot 8-2 \mu \equiv 2.0 \quad$,

$$
\text { Total .. } \overline{2 \cdot 7} \text {," }
$$

In addition to these sampling points, an investigation was made of the content of the general atmosphere in the shop. Positions were taken at least $10 \mathrm{ft}$. from any operator. The result showed that the aluminium dust had settled out by reason of its gross particle size, but that there was a persistent concentration of the very fine transparent fraction of aluminium oxide. 


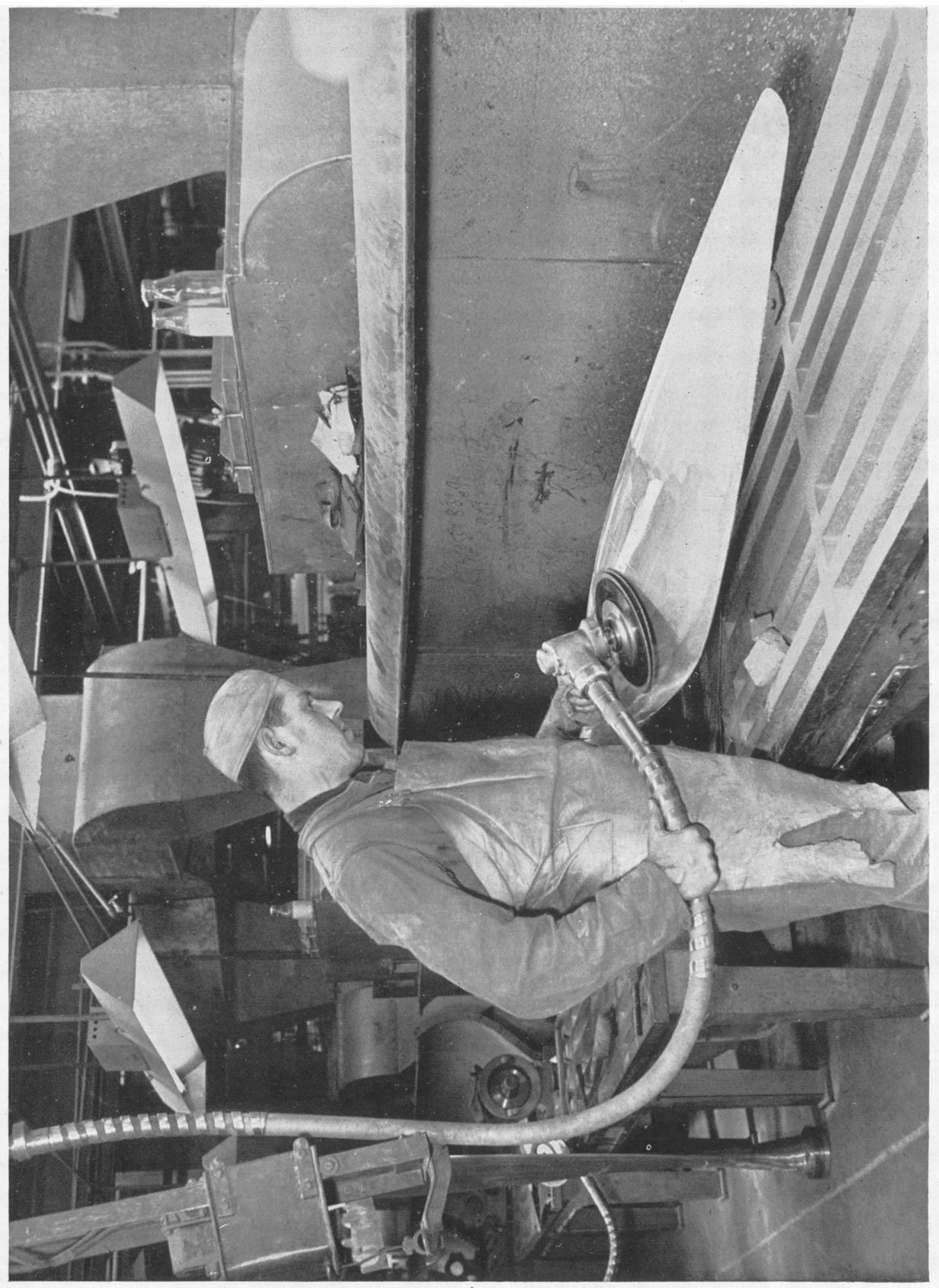



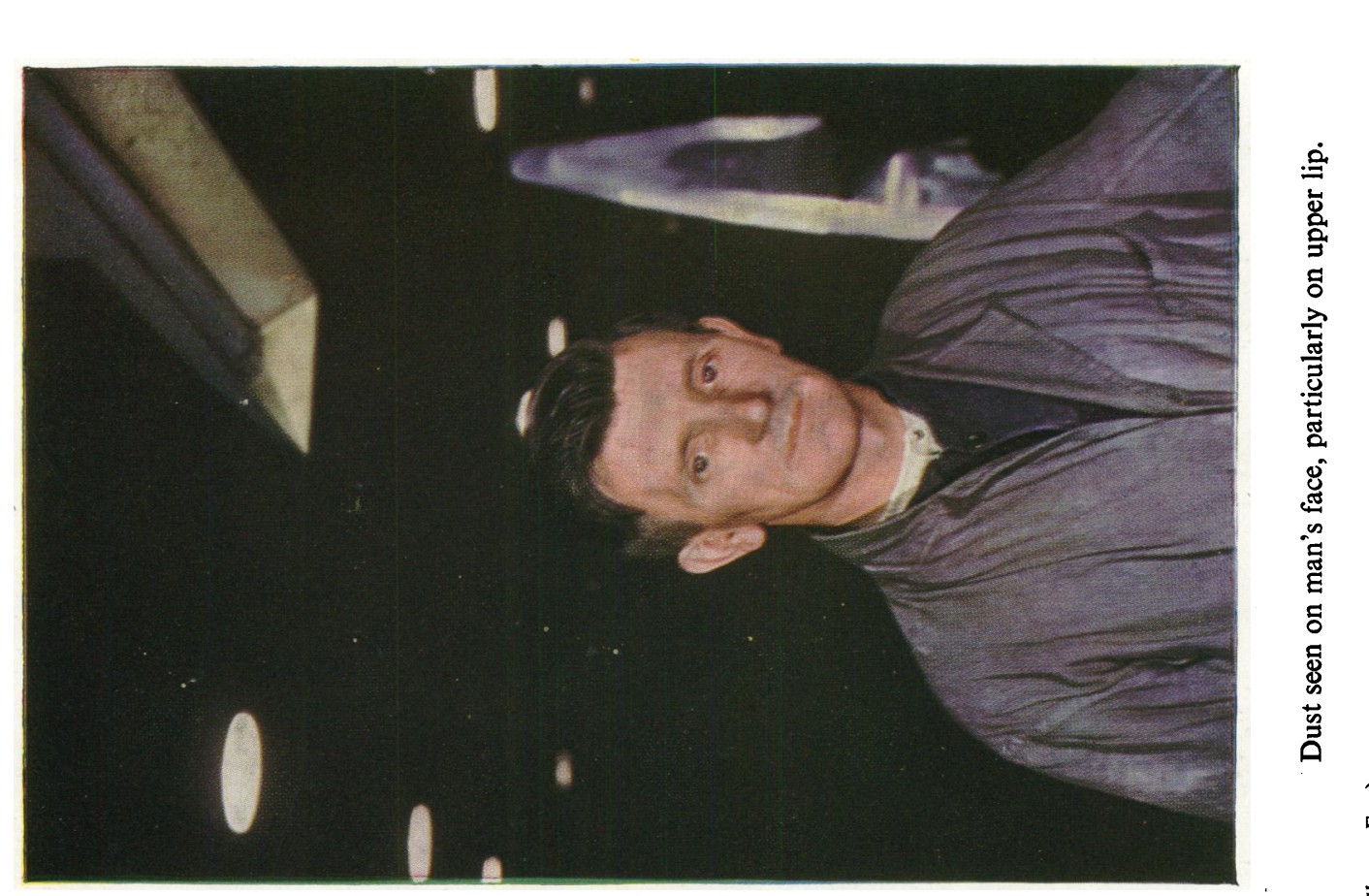

$\omega$ 
All particles were less than $1 \mu$ and were about 2500 per c.c.

2000 per c.c. less than $0.2 \mu \quad \equiv 0.02 \mathrm{mg} . / \mathrm{m}^{3}$ 425, between $0.2 \mu$ and $0.4 \mu \equiv 0.04$

$$
75 \quad \text { " }, \quad 0.4 \mu \text { and } 0.8 \mu \equiv 0.03 \quad \text { Total } \quad \text { 0.09 }
$$

It is reasonable to assume from these results that the softer duralumin metal is cut by the hard abrasive forming gross particles which readily settle out and which stand a good chance of being trapped by the nose and upper respiratory passages of the operator.

Examination of the general air, however, suggests that very stable concentrations of finely dispersed aluminium oxide abrasive of concentration of the order of $0.1 \mathrm{mg} . / \mathrm{m}^{3}$ are constantly present despite the ventilation changes. These values are higher nearer to the grinder $\left(0.24 \mathrm{mg} . / \mathrm{m}^{3}\right)$, and much higher proximal to the polisher $\left(2.7 \mathrm{mg} . / \mathrm{m}^{3}\right)$. Such particles may conceivably be breathed deeply into the lungs.

Clinical Findings. All the grinders and polishers of propellers in one factory were interviewed and their occupational histories were taken. Twentyseven claimed to have some cough, and ten to be somewhat short of breath, but these symptoms did not appear to cause them inconvenience.

Sick Records.-The sick records of the group were examined and compared with a similar group of workers in a machine shop belonging to the same company. This analysis showed no difference of statistical significance between the two groups. It was as follows (Table 3) :

TABLE 3

NUMBER OF SICKNESSES RECORDED UNDER

\begin{tabular}{|c|c|c|c|}
\hline \multicolumn{2}{|c|}{ Diagnosis } & $\begin{array}{l}\text { Aluminium } \\
\text { propeller } \\
\text { grinders (97) }\end{array}$ & $\begin{array}{c}\text { Machine } \\
\text { shop } \\
\text { workers }(100)\end{array}$ \\
\hline \multicolumn{2}{|c|}{$\begin{array}{l}\text { Diseases of respiratory } \\
\text { tract, coryza, etc. }\end{array}$} & 9 & $41^{*}$ \\
\hline Influenza.. & .. & 9 & 15 \\
\hline Tracheal & .. & 4 & 2 \\
\hline Bronchial & & 2 & 5 \\
\hline \multicolumn{4}{|c|}{ Diseases of digestive system: } \\
\hline Gastric & .. & 10 & 19 \\
\hline Duodenal & .. & 0 & 2 \\
\hline Rheumatism, etc. & .. & 11 & 7 \\
\hline Injuries & .. & 5 & 6 \\
\hline Skin diseases & .. & 2 & 1 \\
\hline Hernia & .. & 2 & 1 \\
\hline Psycho-neurosis & .. & 6 & 8 \\
\hline \multirow[t]{2}{*}{ Other causes } & .. & 12 & 36 \\
\hline & .. & 74 & 143 \\
\hline
\end{tabular}
GIVEN DIAGNOSIS DURING THE YEAR 1943

Examination of the sick records and previous histories of the workers showed that none of them had ever suffered from asthma or had a spontaneous pneumothorax.

The age and sex of the group was as follows :-

\begin{tabular}{cccccccc} 
& \multicolumn{3}{c}{ Males } & Females & \multicolumn{4}{c}{ Males } & Females \\
$20-24$ & $\ldots$ & 4 & 1 & $40-44$ & $\ldots$ & 11 & 1 \\
$25-29$ &. & 15 & - & $45-49$ & $\ldots$ & 12 & - \\
$30-34$ &. & 22 & - & $50-54$ & $\ldots$ & 2 & 2 \\
$35-39$ &. & 19 & 1 & Over $55 .$. & 2 & - \\
\hline
\end{tabular}

* Thirty-three under four days.
Of the 92 workers 37 were at the job for more than 5 years and 31 for more than 2 years.

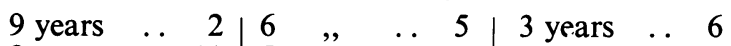

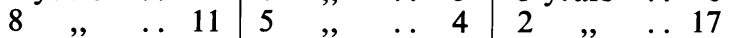
\begin{tabular}{llllllll|llll}
7 &, &. & 11 & 5 &, & $\ldots$ & 4 & 2 &, & $\ldots$ & 17 \\
& & &
\end{tabular}

Blood Counts.-Blood counts were performed on workers in the propeller grinding shop who gave their permission for the investigation. Fifty-seven volunteered and their counts were compared with a group of 60 men from a machine shop. There was no distinct difference; the aluminium workers tended to have a polymorphonuclear leucocytosis. (See Figs. 2-5.) This is the opposite to Goralewski's

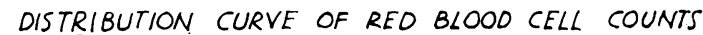
ON 55 MALE DURALUMIN PROPELLER CRINDERS AND POLISHERS AND 58 MALE CONTROLS FROM MACHINE SHOP

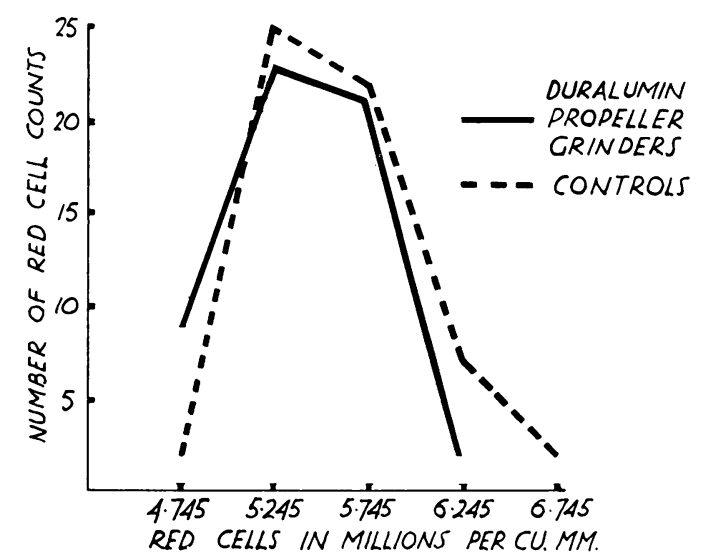

FIG. 2.

findings. There is a general tendency towards a leucopenia with a relative lymphocytosis in this country at the present time, as shown by work by Britton (1943), Mottram (1943), Hamilton-Paterson and Browning (1944), and is our own finding in other factories. This may be an influence of blackout conditions, and if these are as bad in German aluminium factories as is suggested by Koelsch, they may account for the findings of Goralewski.

$X$-Ray Findings.-A mobile $\mathrm{x}$-ray plant was taken to the factory and $x$-rays of the chest were taken of DISTRIBUTION CURVE OF WHITE CELL COUNTS ON 55 MALE DURALUMIN PRODELLER CRINDERS ANO POLISHERS AND 58 MALE CONTROLS FROM MACHINE SHOP

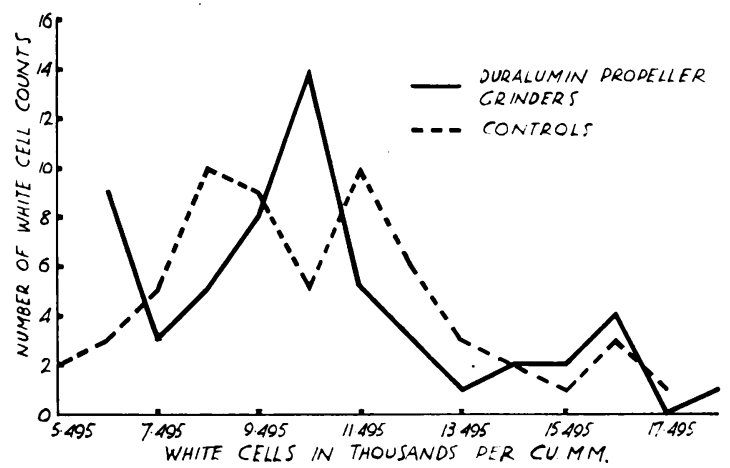

FIG 3. 


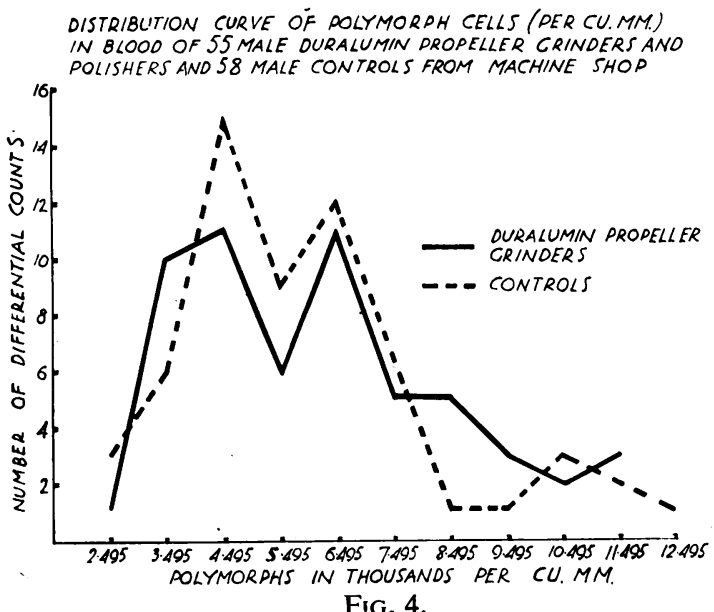

FIG. 4.

DISTRIBUTION CURVE OF HAEMOCLOBIN PER CENT (ALKALINE HAEMATIN - PHOTO ELECTRIC CELL METHOD 13.8C HAEMOCLOBIN PER $10 O$ C.C. BLOOD - 100 PER (ENT) FOR 55 MALE DURALUMIN PROPELLER GRINDERS AND 58 MALE CONTROLS FROM MACHINE SHOP

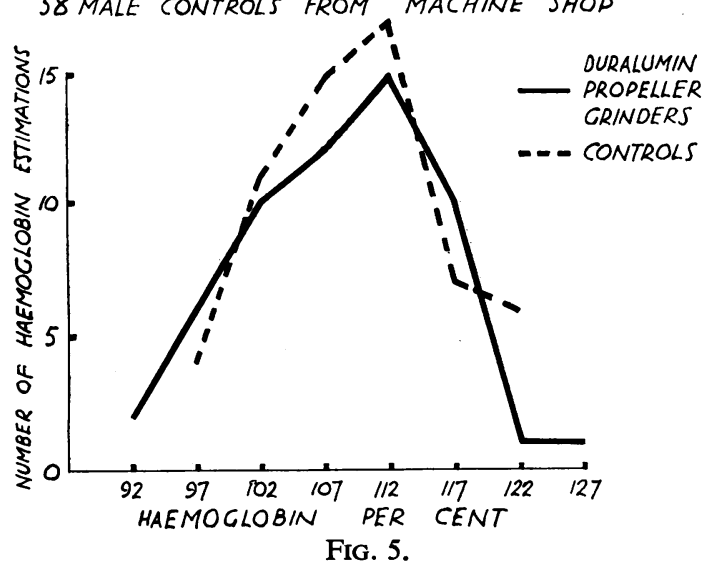

92 out of the 97 workers who were exposed to aluminium dust. The other 5 declined, but there was no reason to suppose they had any disease in their lungs. Full-sized 15 in. $\times 12$ in. radiograms were taken and were reported on independently by Dr. M. H. Jupe and Dr. D. Jennings. There was no evidence in any of them of reticulation. In seven instances, however, there were shadows in the peripheral part of the lung which were different from the ones usually found in this situation (Fig. 6). It is conceivable that they may be due to concretions of aluminium dust. They were not related to symptoms. There were two active cases of pulmonary tuberculosis and one case which was probably arrested. These were all advised to seek treatment. There was also one example of well-marked silicotic nodulation, but this man had worked for 21 years in the South Wales coalfield.

We would like to thank Dr. M. H. Jupe and Dr. D. Jennings for their kind co-operation in interpreting the radiograms, to $\mathrm{Mr}$. $\mathrm{H}$. J. Ferrier of the British Red Cross Society for his help in taking the films, to Dr. N. Spoor and Dr. J. Graham for the environmental studies, and to Miss M. E. Thompson for the haematological investigation.

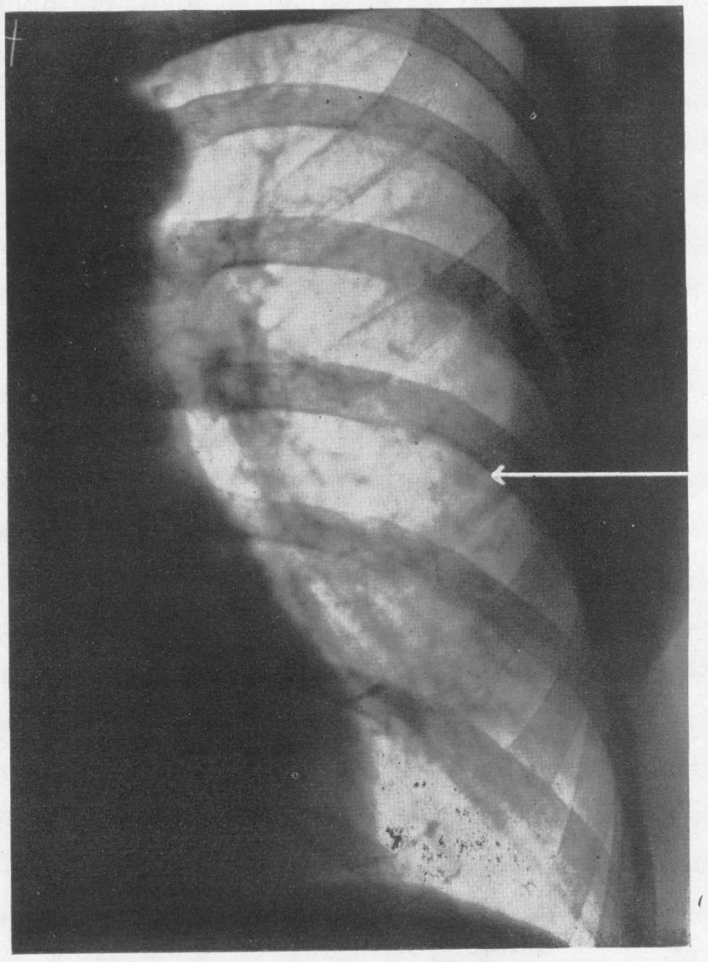

FIG. 6.-Contact film showing opacities seen in the periphery of the lung. The significance of these is uncertain.

\section{Summary}

The literature of the effect of aluminium and alumina is reviewed. Occupational histories, blood counts, and $\mathrm{x}$-rays were taken on duralumin propeller grinders in an aircraft factory. The sick absence records were studied. There is no evidence that this dust produces any disease of the trachea, bronchi, or lungs.

\section{REFERENCES}

Britton, J. C. (1943). Lancet, 2, 289.

Cotter, L. H. (1943). J. industr. Hyg., 25, 421.

Denny, J. J., Robson, W. D., Irwin, D. A. (1937), Canad. med. Ass. J., 37, 1.

,,,$---(1939)$. Ibid., 40, 213.

Evang, K.'(1938). Nord Hyg. Tidskr., 19, 117

Front, J. S., and Kirsner, J. B. (1942), J. Lab. clin. Med., 27, 1598.

Goralewski, G. (1939). Arch. Gewerbepath. u. hyg., 9, 676.

(1940). Ibid., 10, 384

(1941). Ibid., 11, 106.

(1943), Dtsch. Tuber.-bl., 17, 3

_ and Jäger, R. (1943). Arch. Gewerbepath. $u$. hyg., 11, 102.

Hamilton-Paterson, J. L., and Browning, E. (1944). Brit. med. J., 1, 349.

Hill, A. B. (1936). Ibid., 2, 1274.

Jäger, R., and Jäger, F.'(1941). Arch. Gewerbepath. u. hyg., 11, 117.

Koelsch, F. (1942). Beitr. klin. Tuber., 97, 688.

Medical Research Council, Industrial Pulmonary Diseases Committee (1936). Brit. med. J., 2, 1273.

Mottram, J. C. (1943). Lancet, 2, 588.

Riedl, L. (1939). Cásop. lék. cesk., 78, 1236. 